\title{
Comparing the Effect of Fillers on the Mechanical Properties of Recycled Low Density Polyethylene Composites Under Non-Weathered and Weathered Conditions
}

\author{
Olutosin O. Ilori, Ibiyemi. A. Idowu, and Kehinde M. Adeleke
}

\begin{abstract}
This work compared the effect of fillers on the mechanical properties of recycled low-density polyethylene composites under non-weathered and weathered conditions. Pure water sachet wastes, glass wastes were sourced from dump-site at Obafemi Awolowo University, Ile-Ife, Nigeria, while the talc was sourced from Lagere, Ile-Ife, Nigeria. Recycling of plastic bags (low-density polyethylene) and the preparation of recycled low-density polyethylene (RLDPE)/glass, RLDPE/ talc and RLDPE/glass/talc composites were carried out using a furnace at compositions of 0 to $40 \%$ in steps of $10 \%$ by weight. The mixtures were then poured into hand-laid mould for tensile, impact and hardness tests. The samples were divided into two groups; one group was subjected to natural weathering conditions. The results of mechanical tests carried out were subjected to a paired t-test. The study concluded that there was no significant difference between the non-weathered and weathered samples. This implies that both talc and glass were able to reinforce recycled low density polyethylene (RLDPE) under both conditions and can help resist degradation.
\end{abstract}

Index Terms-Recycled Low Density Polyethylene (RLDPE); Weathering; Glass; Talc; Mechanical Properties.

\section{INTRODUCTION}

The indiscriminate disposal of waste in our environment is one of the major concerns that have aborted most of the efforts of international, federal, state and city authorities [1]. This could be in form of refuse, garbage and sludge. To tackle the issue of this waste, municipal solid waste management was introduced. Reference [2] observed that municipal solid wastes contribute about 25 million tonnes of waste by weight on Nigeria landfills annually. Waste generation scenario in Nigeria has been of great concern both globally and locally. Solid waste management in Nigeria is characterized by inefficient collection methods, insufficient coverage of the collection system and improper disposal of solid waste [3]. In a few decades the landfill capacity could be exhausted in the urban settlements and to reduce the volume of plastic wastes that goes to landfills or litters the environment, there are three options, namely; recycling, incineration and landfilling [4]. Recycling of municipal

Published on May 14, 2018.

O. O. Ilori and K. M. Adeleke are affiliated with Department of Mechanical Engineering, Adeleke University, Ede, Nigeria.

I. A. Idowu is with Department of Mechanical Engineering, Obafemi Awolowo University, Ile-Ife, Nigeria.

Corresponding Author: Olutosin O. Ilori,

ilori.olutosin@adelekeuniversity.rdu.ng plastic waste is a lot energetic task attributable to the fact that the materials are usually a mixture of several polymers which make the processing more difficult and also limits the number of potential applications [5].

The use of fillers in many commercial polymers is for the enhancement in stiffness, strength, dimensional stability, toughness, heat distortion temperature, damping, impermeable and cost reduction. An improvement in composite physical properties is directly related to particle size, whereby the smaller particulate fillers impart greater reinforcement [6]. Particle-size distribution and particle shape also have significant effects on composite reinforcement.

The weathering process occurs as a result of the combined effect of water absorption and exposure to ultra-violet radiation $(\mathrm{u}-\mathrm{v})$. Absorption of water can have a plasticizing action on plastics which increases flexibility but on elimination of the water results in embrittlement while u-v causes breakdown of the bonds in the polymer chain. The result is general deterioration of physical properties such as loss of colour or clarity or both [7].

Low density polyethylene (LDPE) is semi-rigid and translucent material with useful properties like toughness, flexibility, resistance to chemicals and low water absorption. LDPE is resistant to organic solvent at room temperature, has a high impact resistance and excellent corrosion resistance [8]. However, LDPE has a poor ultraviolet (UV) resistance, low strength and stiffness. Its maximum working temperature is also low and it is susceptible to environmental stress attack. Researchers have established that certain fillers such as clay, kenaf powder and calcium carbonate can be added to recycled low and high density polyethylene (LDPE / HDPE) to improve their mechanical properties but it has also been established from those works that increase in filler content reduces the tensile strength of recycled polyethylene due to the inability of filler to support stresses transferred from polymer matrix [9]. The physical and mechanical characteristics of composites can be modified by adding a filler phase to the matrix body during the composite preparation established by [10]. The incorporation of filler in composite is to improve mechanical and tribological properties. Also, the mechanical properties of sisal, jute and glass fiber reinforced polyester composites were examined by [11]. They reported that the addition of glass fiber into jute fiber composite resulted in maximum tensile strength; jute and sisal mixture composites sample is capable of 
having maximum flexural strength and obtained maximum impact strength for the sisal fiber composite. Similarly, [12] studied the mechanical properties of jute/glass reinforced polyester with water absorption condition. It was established that the jute composite is not suitable for underwater applications.

This study is aimed at enhancing and analysing the mechanical properties of RLDPE composites with addition of fillers under different conditions. The objective of this research is to compare the effect of fillers on the mechanical properties of the recycled low-density polyethylene composites under non-weathering and weathering conditions.

\section{EXPERIMENTAL PROCEDURE}

\section{A. Materials}

The materials used for this experiment are waste pure water sachets (made from low density polyethylene), glass and talc powder (as fillers). The waste pure water sachets were gathered from refuse dumps of Obafemi Awolowo University, Ile-Ife, Nigeria. The waste sachets were cleaned by washing to remove dirt, cut into smaller sizes and airdried. The fillers (glass and talc) were sourced from local market in Ile-Ife. Talc was ground into particles using a disc grinder, sieved to particle size of $75 \mu \mathrm{m}$ and oven-dried in a vacuum oven at $120^{\circ} \mathrm{C}$ for 24 hours. Also, the glass was pulverized with hammer mill and sieved to a particle size of $75 \mu \mathrm{m}$.

\section{B. Preparation of the RLDPE Composites}

The waste pure water sachets were melted in a crucible placed in a furnace at $110^{\circ} \mathrm{C}$ and mixed with talc at compositions of 0 to $40 \%$ by weight at interval of $10 \%$ and mixed thoroughly for proper dispersion into the LDPE. The molten mixture was then poured into hand laid moulds. Two (2) samples were produced at different levels of composition for this filler and were replicated thrice to make a total of thirty (30) samples. This procedure was repeated using glass particles and blend of talc with glass particles as fillers in place of talc at ratio $1: 1$.

\section{Weathering Test}

Weathering factors includes sunlight, temperature, moisture and micro-biological attack. Of these factors, sunlight was considered in analysing the weathering effects on recycled LDPE because is the most critical for plastic degradation and ageing leading to loss of mechanical properties. Fifteen (15) samples produced for each of the fillers were exposed to sunlight for a period of eight (8) weeks and subsequently subjected to mechanical test.

\section{Mechanical Characteristics}

All samples produced at different levels of composition for the fillers under non-weathering and weathering conditions were subjected to hardness, impact and tensile tests and the average values were recorded.

\section{E. Data Analysis}

The data collected were subjected to a paired t-test. Paired t-test is generally used when measurements are taken from the same subject, before and after manipulation or intervention.

\section{RESULTS AND DISCUSSION}

The average values of mechanical tests obtained for each of the fillers under non-weathering and weathering conditions at different levels of composition are presented in Tables I - VI. Statistical analysis was conducted on the data collected; a paired t-test was used to compare the effect of the fillers on the mechanical properties of RLDPE composites at both weathering conditions.

TABLE I: AVERAGE MECHANICAL PROPERTIES OF RLDPE COMPOSITES FILLED WITH GLASS (NON-WEATHERED)

\begin{tabular}{ccccc}
\hline \hline Sample & $\begin{array}{c}\text { Weight of } \\
\text { Filler (\%) }\end{array}$ & $\begin{array}{c}\text { Tensile } \\
\text { Strength } \\
\text { (MPa) }\end{array}$ & $\begin{array}{c}\text { Impact } \\
\text { Strength } \\
\text { (Joules) }\end{array}$ & $\begin{array}{c}\text { Hardness } \\
\text { (BHN) }\end{array}$ \\
\hline 1 & 0 & 5.43358 & 5.168 & 9.60 \\
2 & 10 & 4.01148 & 5.304 & 14.15 \\
3 & 20 & 2.00000 & 5.576 & 31.95 \\
4 & 30 & 1.74794 & 5.984 & 35.42 \\
5 & 40 & 0.86449 & 6.392 & 40.65 \\
\hline \hline
\end{tabular}

TABLE II: AVERAGE MECHANICAL PROPERTIES OF RLDPE COMPOSITES FILLED WITH TALC (NON-WEATHERED)

\begin{tabular}{ccccc}
\hline \hline Sample & $\begin{array}{c}\text { Weight of } \\
\text { Filler (\%) }\end{array}$ & $\begin{array}{c}\text { Tensile } \\
\text { Strength } \\
\text { (MPa) }\end{array}$ & $\begin{array}{c}\text { Impact } \\
\text { Strength } \\
\text { (Joules) }\end{array}$ & $\begin{array}{c}\text { Hardness } \\
\text { (BHN) }\end{array}$ \\
\hline 1 & 0 & 5.43358 & 5.1680 & 9.60 \\
2 & 10 & 3.06605 & 5.3040 & 10.80 \\
3 & 20 & 1.56193 & 5.4400 & 27.55 \\
4 & 30 & 0.67231 & 5.5760 & 30.65 \\
5 & 40 & 0.47233 & 5.8480 & 35.20 \\
\hline \hline
\end{tabular}

TABLE III: AVERAGE MECHANICAL PROPERTIES OF RLDPE FILLED WITH THE MIXTURE OF TALC AND GLASS (NON-WEATHERED)

\begin{tabular}{ccccc}
\hline \hline Sample & $\begin{array}{c}\text { Weight of } \\
\text { Filler (\%) }\end{array}$ & $\begin{array}{c}\text { Tensile } \\
\text { Strength } \\
(\mathbf{M P a})\end{array}$ & $\begin{array}{c}\text { Impact } \\
\text { Strength } \\
\text { (Joules) }\end{array}$ & $\begin{array}{c}\text { Hardness } \\
\text { (BHN) }\end{array}$ \\
\hline 1 & 0 & 5.43358 & 5.1680 & 9.60 \\
2 & 10 & 3.08579 & 5.3040 & 10.82 \\
3 & 20 & 1.39040 & 5.5760 & 30.25 \\
4 & 30 & 0.46966 & 5.7120 & 32.05 \\
5 & 40 & 0.25170 & 6.1200 & 38.65 \\
\hline \hline
\end{tabular}

TABLE IV: AVERAGE MECHANICAL PROPERTIES OF RLDPE FILLED WITH GLASS (AFTER EXPOSURE TO SUNLIGHT FOR 8 WEEKS)

\begin{tabular}{ccccc}
\hline \hline Sample & $\begin{array}{c}\text { Weight of } \\
\text { Filler (\%) }\end{array}$ & $\begin{array}{c}\text { Tensile } \\
\text { Strength } \\
\text { (MPa) }\end{array}$ & $\begin{array}{c}\text { Impact } \\
\text { Strength } \\
\text { (Joules) }\end{array}$ & $\begin{array}{c}\text { Hardness } \\
\text { (BHN) }\end{array}$ \\
\hline 1 & 0 & 0.18000 & 4.3520 & 2.94 \\
2 & 10 & 0.98848 & 4.7600 & 6.98 \\
3 & 20 & 0.80995 & 4.9860 & 8.55 \\
4 & 30 & 0.66595 & 5.1680 & 12.25 \\
5 & 40 & 0.49245 & 5.3040 & 15.00 \\
\hline \hline
\end{tabular}

TABLE V: AVERAGE MECHANICAL PROPERTIES OF RLDPE FILLED WITH TALC (AFTER EXPOSURE TO SUNLIGHT FOR 8 WEEKS)

\begin{tabular}{ccccc}
\hline \hline Sample & $\begin{array}{c}\text { Weight of } \\
\text { Filler (\%) }\end{array}$ & $\begin{array}{c}\text { Tensile } \\
\text { Strength } \\
(\mathbf{M P a})\end{array}$ & $\begin{array}{c}\text { Impact } \\
\text { Strength } \\
\text { (Joules) }\end{array}$ & $\begin{array}{c}\text { Hardness } \\
(\mathbf{B H N})\end{array}$ \\
\hline 1 & 0 & 0.18000 & 4.3520 & 2.94 \\
2 & 10 & 2.19475 & 4.8960 & 8.46 \\
3 & 20 & 0.99731 & 5.0320 & 10.24 \\
4 & 30 & 0.49770 & 5.1160 & 15.50 \\
5 & 40 & 0.39257 & 5.1680 & 20.00 \\
\hline \hline
\end{tabular}


TABLE VI: AVERAGE MECHANICAL PROPERTIES OF RLDPE FILLED WITH THE MIXTURE OF TALC AND GLASS (AFTER EXPOSURE TO SUNLIGHT FOR 8

\begin{tabular}{ccccc}
\hline Sample & $\begin{array}{c}\text { Weight of } \\
\text { Filler }(\%)\end{array}$ & $\begin{array}{c}\text { Tensile } \\
\text { Strength } \\
(\mathbf{M P a})\end{array}$ & $\begin{array}{c}\text { Impact } \\
\text { Strength } \\
\text { (Joules) }\end{array}$ & $\begin{array}{c}\text { Hardness } \\
\text { (BHN) }\end{array}$ \\
\hline 1 & 0 & 0.18000 & 4.3520 & 2.94 \\
2 & 10 & 1.27437 & 4.9440 & 3.65 \\
3 & 20 & 0.92210 & 4.9960 & 5.05 \\
4 & 30 & 0.75732 & 5.1680 & 8.42 \\
5 & 40 & 0.34588 & 5.1790 & 11.34 \\
\hline \hline
\end{tabular}

IV. RELATING THE EFFECT OF FILLERS ON THE MECHANICAL PROPERTIES OF RLDPE COMPOSITES UNDER NON-WEATHERED AND WEATHERED CONDITIONS

The paired t-test was used because measurements were taken from the same subject, before and after manipulation/intervention. Two-tailed tests of p-value greater than 0.05 were considered statistically in-significant between non-weathered and weathered composites for the determination of significance.

$\mathrm{H}_{\mathrm{o}}: \mu_{\mathrm{A}}=\mu_{\mathrm{B}}$ there is no difference between the means

$\mathrm{H}_{\mathrm{a}}: \mu_{\mathrm{A}} \neq \mu_{\mathrm{B}}$ there is difference between the means

Reject null hypothesis if $\mathrm{p} \leq 0.05$, Accept null hypothesis if $\mathrm{p}>0.05$

\section{A. Tensile Strengths}

\section{1) Effect of glass on RLDPE}

There is no significant difference in the tensile strengths for non-weathered RLDPE/glass composites $(\mathrm{M}=2.81 \mathrm{MPa}$, $\mathrm{SD}=1.86 \mathrm{MPa})$ and weathered RLDPE/glass composites $(\mathrm{M}$ $=0.63 \mathrm{MPa}, \mathrm{SD}=0.31 \mathrm{MPa}) ; \mathrm{t}(4)=2.472, \mathrm{p}=0.069(\mathrm{p}>$ $0.05)$. This result suggests that glass was able to reinforce RLDPE at both conditions.

\section{2) Effect of talc on RLDPE}

Also, there is no significant difference in the tensile strengths for non-weathered RLDPE/talc composites $(\mathrm{M}=$ $2.24 \mathrm{MPa}, \mathrm{SD}=2.06 \mathrm{MPa})$ and weathered RLDPE/talc composites $(\mathrm{M}=0.85 \mathrm{MPa}, \mathrm{SD}=0.81 \mathrm{MPa}) ; \mathrm{t}(4)=1.422, \mathrm{p}$ $=0.228(\mathrm{p}>0.05)$. This shows that talc was able to reinforce RLDPE under weathered and non-weathered conditions.

\section{3) Effect of glass/talc on RLDPE}

Furthermore, from the statistical analysis, there is no significant difference in the tensile strength for nonweathered RLDPE/glass/talc composites $(\mathrm{M}=2.13 \mathrm{MPa}, \mathrm{SD}$ $=1.16 \mathrm{MPa})$ and weathered RLDPE/glass/talc composites $(\mathrm{M}=0.69 \mathrm{MPa}, \mathrm{SD}=0.44 \mathrm{MPa}) ; \mathrm{t}(4)=1.397, \mathrm{p}=0.235$ ( $>0.05)$, it shows that glass and talc were able to reinforce RLDPE under weathered and non-weathered conditions.

\section{B. Impact Test}

\section{1) Effect of glass on RLDPE}

Analysis carried out on the average result reveals that there is no significant difference in the impact strengths for non-weathered RLDPE/glass composites $(\mathrm{M}=5.68 \mathrm{~J}, \mathrm{SD}=$ $0.50 \mathrm{~J})$ and weathered RLDPE/glass composites $(\mathrm{M}=4.91 \mathrm{~J}$, $\mathrm{SD}=0.37 \mathrm{~J}) ; \mathrm{t}(4)=2.324, \mathrm{p}=0.065(\mathrm{p}>0.05)$. This means glass was able to reinforce RLDPE at the two conditions.

\section{2) Effect of talc on RLDPE}

Likewise, there is no significant difference in the impact strengths for non-weathered RLDPE/talc composites $(\mathrm{M}=$ $5.47 \mathrm{~J}, \mathrm{SD}=0.26 \mathrm{~J})$ and weathered RLDPE/talc composites $(\mathrm{M}=4.91 \mathrm{~J}, \mathrm{SD}=0.32 \mathrm{~J}) ; \mathrm{t}(4)=2.422, \mathrm{p}=0.328(\mathrm{p}>0.05)$. Talc was able to reinforce RLDPE under weathered and non-weathered conditions.

\section{3) Effect of glass/talc on RLDPE}

There is no significant difference in the impact strength for non-weathered RLDPE/glass/talc composites $(\mathrm{M}=$ $5.58 \mathrm{~J}, \quad \mathrm{SD}=0.37 \mathrm{~J})$ and weathered RLDPE/glass/talc composites $(\mathrm{M}=4.93 \mathrm{~J}, \mathrm{SD}=0.34 \mathrm{~J}) ; \mathrm{t}(4)=2.656, \mathrm{p}=0.452$ $(p>0.05)$. These results suggest glass and talc were able to reinforce RLDPE under weathered and non-weathered conditions.

\section{Hardness Tests}

\section{1) Effect of glass on RLDPE}

There is no significant difference in the hardness properties for non-weathered recycled polyethylene/glass composites $(\mathrm{M}=26.35 \mathrm{BHN}, \mathrm{SD}=13.67 \mathrm{BHN})$ and weathered recycled polyethylene/glass composites $(\mathrm{M}=$ $9.14 \mathrm{BHN}, \mathrm{SD}=4.68 \mathrm{BHN}) ; \mathrm{t}(4)=1.970, \mathrm{p}=0.365$ ( $p>0.05)$. These results suggest glass was able to reinforce RLDPE under weathered and non-weathered conditions.

\section{2) Effect of talc on RLDPE}

There is no significant difference in the hardness properties for non-weathered recycled polyethylene/talc composites $(\mathrm{M}=22.76 \mathrm{BHN}, \mathrm{SD}=11.79 \mathrm{BHN})$ and weathered recycled polyethylene/talc composites $(\mathrm{M}=$ $11.43 \mathrm{BHN}, \mathrm{SD}=6.56 \mathrm{BHN}) ; \mathrm{t}(4)=2.370, \mathrm{p}=0.079$ $(p>0.05)$. These results suggest talc was able to reinforce RLDPE under weathered and non-weathered conditions.

\section{1) Effect of glass/talc on RLDPE}

There is no significant difference in the hardness properties for non-weathered recycled polyethylene/glass/talc composites $(\mathrm{M}=24.27 \mathrm{BHN}, \mathrm{SD}=$ 13.22 BHN) and weathered recycled polyethylene/glass/talc composites $(\mathrm{M}=6.28 \mathrm{BHN}, \mathrm{SD}=3.53 \mathrm{BHN})$ conditions; $\mathrm{t}(4)=2.570, \mathrm{p}=0.082(\mathrm{p}>0.05)$. These results suggest glass and talc were able to reinforce RLDPE under weathered and non-weathered conditions.

The impact test results obtained in this work under two conditions considered agreed with the observation of [13][15] who studied the mechanical properties of particulate filled polymer composites and reported that increase in filler loadings increased the impact strength of a polymer composite even though their experiment was done under non-weathered condition. Also, hardness test results observed are in agreement with the work of [16], [17] who worked on particulate filled polyethylene composites and observed an increase in hardness value as filler content increases; their work was carried out under non-weathered condition. 


\section{CONCLUSION}

Comparing the effects of fillers on the mechanical properties of recycled low-density polyethylene under nonweathering and weathering conditions at different levels of the filler loading $(0,10,20,30,40 \mathrm{wt} \%)$, it was observed that there was no significant difference between the nonweathered and weathered samples. This implies that both talc and glass were able to reinforce recycled low density polyethylene (RLDPE) under both conditions and can help to resist degradation.

\section{REFERENCES}

[1] A.S. Oladepo and O.R. Olorunnimbe, Challenges of waste management and climate change in Nigeria: Lagos State metropolis experience. African Journal Scientific Research, 7(1): 105-109, 2012.

[2] A. Kadafa, J. Murali and K. Mohana. Muncipal solid waste management in Nigeria. Journal of Applied Science and Environment, 35, pp. 56-70, 2013.

[3] T.C. Ogwueleka. Municipal solid waste characteristics and management in Nigeria. Journal of Environmental Health Science and Engineering, 6(3), pp. 173-180, 2009.

[4] I.O. Eze. Effects of Bamboo powder on some Mechanical properties of Recycled Low Density Polyethylene Composites. Journal of Natural and Applied Science, 4(1), pp. 24-35, 2013.

[5] H.P. Blom, J.W. Teh and A. Rudin. PP/PE blends. IV Characterization and compatibilization of blends of postconsumer resin with virgin PP and HDPE, Journal of Applied Polymer Science, 70(11), pp. 2081-2095, 1998.

[6] G. Oprisan. Application of modern polymeric composite materials in Industrial Construction. Journal of Environmental Health Science and Engineering, 5(2), 2010.

[7] S. Thomas, J. Kuruvilla and S.K. Malhotra. Polymer Composites. 1st ed., Wilwy-VCH Verlag \& Co., 2012.

[8] J.L. Jordan, D.T. Casem, J.M. Bradley, A.K. Dwivedi, E.N. Brown and C.W. Jordan. Mechanical Properties of Low Density Polyethylene. Journal of dynamic behavior of materials 2, pp. 411420, 2016.

[9] K. Li. Environmental effects on recycled Plastics. Unpublised M.Sc. Thesis of the University of Adelaide, Australia, 2010.

[10] K.P. Ashik and R.S. Sharma. A review on mechanical properties of natural fiber reinforced hybrid polymer composites. Journal of Minerals and Materials Characterization and Engineering, 3, pp. 420426, 2015.

[11] M. Ramesh, K. Palanikumar and K.H. Reddy. Mechanical property evaluation of Sisal-Jute-Glass fiber reinforced polyester composites Composites: Part B, 48, pp. 1-9, 2013.

[12] M.H. Zamri, H.M. Akil, A.A. Bakar, Z.A.M. Ishak and L.W. Cheng. Effect of water absorption on pultruded Jute/Glass fiber-reinforced unsaturated polyester hybrid composites. Journal of Composite Materials, 46, pp. 51-61, 2012.
[13] S.C. Nwanonenyi, M.U. Obidiegwu and G.C. Onuegbu, Effects of particle sizes, filler contents and compatibilization on the properties of linear low density polyethylene filled periwinkle shell powder. International journal of Engineering and Science, 2(2), pp. 1-8, 2013.

[14] T. Guo, L. Wang, A. Zhang T. Cai, Effect of carbonate on polypropylene. Journal of applied polymer science, 97, pp. 1154 1160, 2005.

[15] D.M. Bigg, Mechanical properties of particulate-filled polymer composite. Journal of Polymer Science, 6(2), pp. 115-122, 1987.

[16] C.U. Atunaya et al., Effects of rice husk filler on mechanical properties of polyethylene matrix composites. International Journal of Current Research and Review, 5(15), pp. 58-65, 2013.

[17] [17] J.O. Agunsoye, S.I. Talabi and O.S Sanni, A study of mechanical behavior of coconut shell reinforced polymer matrix composites. Journal of minerals and materials characterization and Engineering, 11, pp. 774-779, 2012.

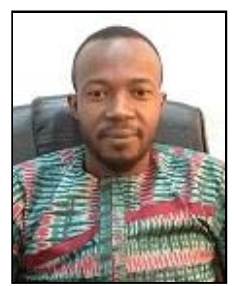

Olutosin O. Ilori obtained B.Tech. (Mechanical Engineering) from Ladoke Akintola University of Technology, Ogbomoso, Nigeria (2006); M.Sc. and $\mathrm{Ph} . \mathrm{D}$ (Mechanical Engineering) from Obafem Awolowo University, Ile-Ife, Nigeria (2010 \& 2015 respectively). He is a lecturer in the Department of Mechanical Engineering, Adeleke University, Ede, Nigeria. His research interest is in Design, Materials and Manufacturing Technology.

Dr. Ilori is a corporate member of Nigeria Society of Engineers and registered Engineer with Council for the Regulation of Engineering in Nigeria.

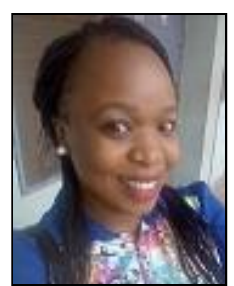

Ibiyemi A. Idowu obtained B.Sc. (Mechanical Engineering) from Olabisi Onabanjo University, Ago- Iwoye, Nigeria (2010); M.Sc. (Mechanical Engineering) from Obafemi Awolowo University, Ile-Ife, Nigeria (2015) and she is currently on her $\mathrm{Ph} . \mathrm{D}$ in the same Institution. Her research interest is in Polymer and nano composities.

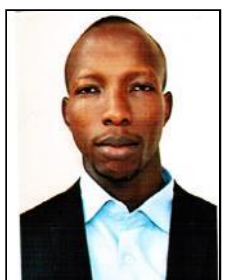

Kehinde M. Adeleke obtained B.Tech. (Mechanical Engineering) from Ladoke Akintola University of Technology, Ogbomoso, Nigeria (2011); M.Eng. (Mechanical Engineering) from Federal University of Technology, Akure, Nigeria (2016) and he is currently on his Ph.D in the same Institution. He is also a lecturer in the Department of Mechanical Engineering, Adeleke University, Ede, Nigeria. His research interest is in Design and Mechatronics. Engr. Adeleke a corporate member of Nigeria Society of Engineers and registered Engineer with Council for the Regulation of Engineering in Nigeria. 